Draft paper to be presented at the EUSA Biannual Meeting in Boston, MA, March $5^{\text {th }}$ 2015.

\title{
Functional constitutionalism in the European Union
}

\author{
Turkuler Isiksel \\ Assistant Professor of Political Science \\ Columbia University \\ LAPA / Perkins Fellow, 2014-2015 \\ Princeton University Program in Law \& Public Affairs
}

Note to readers: This is the second chapter of a book manuscript entitled Europe's Functional Constitution: A Theory of Constitutionalism Beyond the State. The manuscript considers the question of adapting constitutionalism as a form of political and legal ordering to postnational institutions of governance in light of the EU's legal system. It argues, more specifically, that the EU instantiates a new model of constitutional rule, which I propose to term "functional constitutionalism." Constitutional theorists tend to think of constitutional authority as deriving from two key principles: democratic self-rule and individual liberty. Although the EU has many of the features of a constitutional system, it derives its authority from neither of these principles. Instead, its claim to bind member states and their citizens is based on a logic of effective government: the delegation of governance tasks to supranational institutions is commonly viewed and justified a way of responding to policy challenges and systemic imperatives that member states cannot address acting singly. In the first chapter, I argued that this power-building logic is prominent in other, domestic instances of constitutional rule, drawing on work by North and Weingast, Holmes, Elster, and others on the enabling nature of sovereign commitment. In the second chapter, included below, I argue that the EU prioritizes this power-building logic as the primary normative justification for the extraordinarily wide scope of authority wielded by supranational institutions. The chapter explains why the EU legal order should be considered an instance of $a$ ) functional $b$ ) constitutionalism.

Comments are very welcome at nti2002@columbia.edu, but please do not quote, cite, or circulate the chapter without the author's permission. 


\section{Chapter Two}

\section{Functional constitutionalism in the European Union}

In the previous chapter, I argued that the European Union's authority follows a pattern of justification similar to that of domestic constitutional norms: it enables states to make long-term commitments in order to wield their power more effectively. Just as the authors of the Federalist Papers justified the constraints imposed by the proposed US Constitution on the autonomy of the several states with appeals to "the necessity of energetic government," 1 the European Union claims authority over member states and their citizens in order to address "problems that can no longer be solved within the framework of nation-states or by the traditional method of agreements between sovereign states."2 Like certain domestic constitutional norms that aim at effective government, the EU's supranational legal system is "designed with the hope of enhancing the combined problem-solving capacity" they posses. ${ }^{3}$ What I have not yet shown, however, is how this supranational system of sovereign commitment adds up to a constitutional order in its own right. This is the task of the present chapter.

Broadly speaking, the problem of international cooperation can be analogized to the problem of constitutional rule: both are forms of sovereign commitment, and both face the formidable challenge of getting rulers to observe limits on their power. International agreements, like constitutions, pose "parchment barriers against the encroaching spirit of power," 4 and stand in need of various mechanisms to impel sovereign agents to fulfill their obligations. Where the problems are similar, we may expect to see similar solutions, though we cannot assume that the latter exist in any necessary causal relationship to the former. ${ }^{5}$ It is

\footnotetext{
1 Alexander Hamilton, "Federalist No.1: Introduction," in Alexander Hamilton, James Madison, John Jay, The Federalist Papers, ed. Ian Shapiro (New Haven: Yale University Press, 2009), emphasis added. 2 Jurgen Habermas, "The European Nation-State: On the Past and Future of Sovereignty and

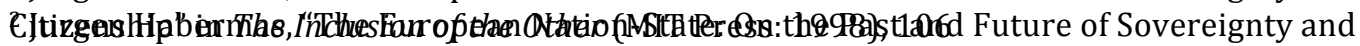
Citizenship" in The Inclusion of the Other (MIT Press: 1998), 106

${ }^{3}$ Stephen Holmes, "To 'Facilitate Future Invasions of the Remainder': Westward Expansion and its Natural Enemies in the Federalist Papers" (October 28, 2014). Draft paper on file with the author.

${ }^{4}$ Federalist No.48

5 This is the assumption that undergirds the functionalist approach to comparative law. In David Kennedy's words, proponents of this approach "[explain] diversity of legal solutions in terms of common policies based on functional needs and evaluating which pattern of rules most effectively carries out policy." David Kennedy, "New Approaches to Comparative Law: Comparativism and International Governance," Utah Law Review, 1997, no.2, pp.545-637, 589 n.73. Dunoff \& Trachtman apply a functionalist approach to fleshing out the similarities between the tasks of domestic and international constitutional law. They argue that these tasks are primarily those of enabling and constraining further norm-making. See Jeffrey L. Dunoff and Joel P. Trachtman, “A Functional Approach to International Constitutionalization,” in Jeffrey
} 
obvious, however, that not all international regimes can be described as constitutional systems in their own right. In what sense can the EU be considered a constitutional order? Or does such consideration entail a category mistake?

Although the 1957 Treaty Establishing the European Economic Community was an agreement among sovereign states, over the first few decades of its existence, it evolved into a sophisticated legal framework. The present-day European Union replicates many institutional devices of constitutional rule at the supranational level, including a functionally delimited, hierarchically ordered system of legal norms, a mechanism of judicial review over member state acts, a schedule of individual rights enforceable in domestic courts, and a supranational executive charged with making, implementing, and monitoring compliance with norms. Each of these features responds to the problem of sovereign commitment, and each is familiar from the domestic context. For these reasons, scholars have argued since the 1980s that the European Community (and its successor, the European Union) should be considered in constitutional terms. As Joseph Weiler put it,

The constitutional thesis claims that in critical aspects the Community has evolved and behaves as if its founding instrument were not a Treaty governed by international law but, to use the language of the European Court of Justice, a constitutional charter governed by a form of constitutional law. ${ }^{6}$

Most versions of the "constitutional thesis" cast the European Court of Justice (now, the Court of Justice of the European Union, or CJEU) as the architect of this supranational legal order. ${ }^{7}$ The story has been told many times: through its farreaching interpretation of the relatively sparse provisions of the Treaty of Rome, the Court shepherded the member states, each with their distinct legal systems, under a dense canopy of supranational legal norms. ${ }^{8}$ Proponents of the constitutional thesis maintain that this canopy is held up by three pillars. The first of these is the doctrine of the supremacy of EU law. In a series of landmark rulings beginning with Costa $\mathrm{v}$. ENEL in 1964, ${ }^{9}$ the Court proclaimed that EC law took precedence over the laws of member states in the event of a conflict. According to the Court's long-standing doctrine, EU law must take precedence even over a member state's constitutional

\footnotetext{
L. Dunoff and Joel P. Trachtman (eds), Ruling the World? Constitutionalism, International Law, and Global Governance (Cambridge: Cambridge University Press, 2009), 4, 10.

${ }^{6}$ J.H.H. Weiler, "The Reformation of European Constitutionalism," Journal of Common Market Studies, vol.35 (1997), no.1, pp.97-131, at 97

${ }^{7}$ Alec Stone Sweet, The Judicial Construction of Europe (Oxford University Press, 2004); Susanne K. Schmidt and R. Daniel Kelemen, The Power of the European Court of Justice (London: Routledge, 2013).

${ }^{8}$ For authoritative accounts of this process, see Joseph Weiler, "The community System: the dual character of supranationalism," Yearbook of European Law, vol.1 (1981), pp.268-306; Karen Alter, Establishing the Supremacy of European Law (Oxford University Press, 2001); Alec Stone Sweet, The Judicial Construction of Europe (Oxford University Press, 2004).

${ }^{9}$ Case 6/64, Flaminio Costa v. E.N.E.L. [1964] ECR 585
} 
norms in the event of a conflict, (an assertion that has been and continues to be challenged by national constitutional courts). ${ }^{10}$

Second, through the piecemeal and sometimes grudging acceptance of the supremacy doctrine by national courts, a system of judicial review has taken shape that integrates EU law into the legal systems of member states as a partially autonomous source of normative authority. Under the preliminary ruling procedure, national courts are empowered (and courts of last instance are required) to refer questions about the application of European law to the Court. ${ }^{11}$ Over time, they have been directed by the CJEU to disregard any national legislation that comes into conflict with European law. This mechanism has not only enabled the CJEU to co-opt domestic courts into a European judiciary with a supranational court as its primary guide, ${ }^{12}$ but has also given ordinary national courts powers of judicial review normally reserved for constitutional courts, thus revising the domestic constitutional systems of member states in areas touched by EU law. ${ }^{13}$ Moreover, because it is their own courts rather than a distant supranational body ordering member states to fulfill their obligations, supranational law has enjoyed a remarkable degree of application within member states.

The doctrine of supremacy is one of an array of features that collectively lend EU law a highly entrenched status. The relative difficulty of modifying constitutional norms in comparison to the ordinary legislative process is a fairly common, though not uniform, feature of constitutional systems. Likewise in the EU, treaty provisions have a "super-entrenched" status, with most amendments requiring unanimous approval and ratification by 28 member states. ${ }^{14}$ Although the 2009 Treaty of Lisbon introduced a so-called "simplified revision procedure" for certain treaty amendments, these still require the relatively onerous conditions of a unanimous Council vote and approval by the European Parliament. ${ }^{15}$ Even the revision of ordinary EU law is arduous, requiring either a qualified majority or unanimity among member states representatives in the Council, along with various complex

\footnotetext{
10 Case 106/77, Amministrazione delle Finanze dello Stato v. Simmenthal SpA [1978] ECR 629; Case C213/89, The Queen $v$ Secretary of State for Transport, ex parte: Factortame Ltd and others [1990] ECR I-2433

${ }^{11}$ Art 267 TFEU (ex-Art 177)

12 Stone Sweet, Judicial Construction of Europe; Anne-Marie Burley and Walter Mattli, "Europe before the Court," International Organization, vol. 47 (1993), no.1, pp. 41-76. See also their more detailed account of the motives underlying the national courts' cooperation with the ECJ in Water Mattli and Anne-Marie Slaughter, Constructing the European Community Legal System from the Ground up (Florence: EUI Working Paper RSC, 1996). See also, Renaud Dehousse, The European Court of Justice: The Politics of Judicial Integration (New York: St. Martin's Press, [1994] 1998).

${ }^{13}$ Eric Stein, "Lawyers, Judges, and the Making of a Transnational Constitution," American Journal of International Law, Vo.75 (1981), pp.1-27, 13; Stone Sweet, Judicial Construction of Europe; Mitchel de S. -0. -l'E Lasser, Judicial Deliberations: A Comparative Analysis of Transparency and Legitimacy (Oxford: Oxford University Press, 2004), 225; Miguel Poiares Maduro, "Sovereignty in Europe: The European Court of Justice and the creation of a European political community," in Mary L. Volcansek \& John F. Stack, Jr. (eds), Courts Crossing Borders: Blurring the Lines of Sovereignty (Durham, NC: Carolina Academic Press, 2005)

${ }^{14}$ Christine Reh, "The Lisbon Treaty: De-Constitutionalizing the European Union?", Journal of Common Market Studies, vol.47 (2009), no.3, pp.625-50, 635

${ }^{15}$ Art 48 (6-7) TEU.
} 
procedures of input by the European Parliament. Finally, all EU norms (that is, secondary legislation as well as treaty provisions) have entrenched status vis-à-vis domestic law, given that they cannot be modified through the domestic legislative process. Even state-by-state opt-outs must be negotiated at the Council or at an intergovernmental conference. In fact, one of the key reasons why the European Court has been able to position itself as an influential institution in the constitutional development of the European Union is owing to the difficulty of modifying the treaty structure. ${ }^{16}$ Taken together, these factors place the supranational legal order quite far along the continuum of entrenchment.

The third pillar of the supranational legal order is the doctrine of direct effect. In 1963, the Court of Justice ruled that certain provisions of the Treaty of Rome give rise to individual rights that could be relied on by individual litigants before national courts. ${ }^{17}$ In the ensuing decades, the Court gradually expanded the remit of the doctrine of the direct effect of European law by finding more and more Treaty provisions and directives as capable of giving rise to individual rights. Consequently, member state nationals (after the Treaty of Maastricht, Union citizens) became the holders of a series of rights originating exclusively from European law. The nucleus of this regime is rights related to cross-border economic activity. The Court of Justice conveys the importance of the freedoms of movement of persons, services, goods, and capital, by referring to them as "fundamental freedoms." The normative ambiguity of this term is further discussed in Chapter 3.

To the extent that the EU legal order regards individuals as its legal subjects and gives rise to rights that they may claim before national courts, it is considered to have "moved... beyond the traditional separation of international public law and domestic law."18 Direct effect not only makes supranational norms an automatic part of domestic law, but it also establishes a capacity on the part of the EU to "carry its agency to the persons of the citizens." 19 These last words are borrowed from Alexander Hamilton, who in 1787 cited "the power of extending its operations to individuals" as the most important criterion of the efficacy of a federal system in eliciting compliance from its constituent units. ${ }^{20}$ According to Hamilton, the qualitative leap from the largely intergovernmental Articles of Confederation to the

\footnotetext{
${ }^{16}$ Stone Sweet, Judicial Construction of Europe, 66

${ }^{17}$ According to the ECJ, Treaty provision must be "clear," "unconditional," must give rise to "a negative obligation" on the part of states and not be dependent on implementing measures in order to qualify for direct effect. Case 26/62, Van Gend en Loos v. Nederlandse Administratie der Belastingen [1963] ECR 1. The Court later relaxed these criteria, choosing to give direct effect to the "principle" of equal pay for equal work contained in ex-Art $119 \mathrm{EC}$, which obligation was rather general, imprecise, and not necessarily "negative." See Case 43/75 Defrenne v. SABENA [1976] ECR 455

${ }^{18}$ Ernst-Joachim Mestmäcker, "On the Legitimacy of European Law," Rabels Zeitschrift für ausländisches und internationals Privatrecht, vol. 58 (1994), no.4, pp. 615-35, 622. Pierre Pescatore, "The Doctrine of 'Direct Effect': An infant disease of Community law," European Law Review, vol.8 (1983), pp. 155-177, 158; Joseph Weiler, "The Transformation of Europe," Yale Law Journal, vol.100 (1991), pp. $2403-$ 2483.

${ }^{19}$ Federalist No.16

${ }^{20}$ Hamilton writes, "But if the execution of the laws of the national government should not require the intervention of the State legislatures, if they were to pass into immediate operation upon the citizens themselves, the particular governments could not interrupt their progress without an open and violent exertion of an unconstitutional power." Federalist No. 16
} 
proposed US Constitution was that the former is based on the "principle of legislation for states or governments, in their corporate or collective capacities, and as contradistinguished from the individuals of which they consist."21 By designating individual citizens as its immediate subjects, the European legal order, like the US Constitution, vested them with the capacity to enforce states' obligations. In announcing the direct effect doctrine in Van Gend en Loos, the European Court of Justice justified it not on the basis of the moral import of protecting individual rights, but on the basis of protecting the efficacy of the supranational order by enlisting the "vigilance" of the individuals concerned. The Court's insight turned out to be prescient. As the direct addressees of the supranational law, citizens of member states have indeed helped to hold member states to their obligations.

In 1986, the European Court of Justice carried the European legal order's three decades of development to its high water mark by calling the Treaty of Rome the "constitutional charter" of the European Community. ${ }^{22}$ It argued that "The European Economic Community is a community based on the rule of law, inasmuch as neither its Member States nor its institutions can avoid a review of the question of whether the measures adopted by them are in conformity with the basic constitutional charter, the Treaty." ${ }^{23}$ In a formulation it has regularly repeated since, the Court held in Les Verts that "the EC Treaty [establishes] a complete system of legal remedies and procedures designed to enable the Court of Justice to review the legality of acts of the institutions." 24 The Court's formulation reflects a fairly standard conception of the rule of constitutional law, that is to say, the principle that no crevice of public power should be exempt from the comprehensive sweep of constitutional scrutiny. ${ }^{25}$ Accordingly, the Court reasoned that within its functionally delimited sphere of jurisdiction, the authority of the EC Treaty over public institutions is seamless and pervasive, just like that of a conventional constitution.

The Court's Les Verts decision made constitutional language all but unavoidable in subsequent discussions of the nature of the European commonwealth. In the ensuing decades, much of the critical debate over the nature and trajectory of European integration has taken place within the discursive parameters of constitutionalism, even when observers contest the appropriateness of this terminology in the supranational context. The terminological shift in favor of constitutional discourse among European jurists in characterizing the European Union is significant. It represents the conquest of new territory for legal scholars in a disciplinary turf war against international relations scholarship, which has traditionally held that only sovereign states and their capacity to exert violent force

\footnotetext{
${ }^{21}$ Federalist No.15

${ }^{22}$ Case 294/83 Partie Ecologiste 'Les Verts' v. Parliament [1986], ECR 1339

23 ibid, para. 23

${ }^{24}$ Les Verts, para.23

25 The rule of law is, in essence, what Neil MacCormick calls the "minimal virtue" of constitutionalism. MacCormick, Questioning Sovereignty, 103
} 
"matter,"26 and that the law, either as a factual or normative category, is purely epiphenomenal in the international realm. ${ }^{27}$ Thus, part of the insistence on constitutional terminology must be explained in terms of epistemic empowerment: it implies that the development of legal norms, doctrines, and adjudication not only influences state "behavior," but can help reconfigure the unquestioned categories (such as interest, preference, or power) on which international relations scholarship is built.

The penchant for describing the supranational enterprise in constitutional terms did not long remain confined to academic and legal circles. The start of a more assertive political phase of integration after the 1992 Maastricht Treaty generated expectations that after many decades spent on the margins of public debate, the European Union might finally be ready to tread a constitutional path similar to the United States. Just as the Articles of Confederation that barely held together the thirteen states was superseded by a federal framework, proponents of a federal Europe hoped that the newly inaugurated Union would transform from the pragmatic scheme of cooperation among member states into a polity in its own right. Jurgen Habermas argued that such a transformation required an eponymous constitutional document, which would help democratic politics to finally break the shell of the nation-state. ${ }^{28}$ Endorsing Habermas's project in a celebrated 2000 speech, the then German foreign minister Joschka Fischer argued that the time had come to move to a fully-fledged European federation. ${ }^{29}$ Both of these appeals grounded the need for a constitution for the EU on two countervailing considerations; on the one hand, the legitimation problems created by the transfer of power from elected domestic legislatures and democratically accountable executives to supranational institutions attenuated from popular control, and on the other hand, the persistent systemic imperatives that warranted the expansion of supranational decision-making.

The decision by member states at the 2001 European Council meeting in Laeken to explore the possibility of a supranational constitutional document stoked

\footnotetext{
${ }^{26}$ As Waltz memorably put it: "National politics is the realm of authority, of administration, and of law. International politics is the realm of power, of struggle, and of accommodation." Kenneth Waltz, Theory of International Politics (McGraw-Hill, 1979), at 113

${ }^{27}$ For an updated articulation of this position, see Jack L. Goldsmith and Eric A. Posner, The Limits of International Law (New York: Oxford University Press, 2006)

${ }^{28}$ Habermas, The Inclusion of the Other, 161; Jürgen Habermas, "Remarks on Dieter Grimm's 'Does Europe Need a Constitution?'," European Law Journal, vol.1 (1995), no.3, pp.301-306; “Why Europe Needs a Constitution," New Left Review, vol.11(2001), pp.5-26; and essays in The Inclusion of the Other.

${ }^{29}$ Joschka Fischer, "From Confederacy to Federation: Thoughts on the Finality of European Integration," speech delivered at Humboldt University in Berlin, 12 May 2000. Fischer visibly borrowed from Habermas in casting the constitution as a solution for Europe's democratic deficit: "These three reforms - the solution of the democracy problem and the need for fundamental reordering of competences both horizontally, i.e., among the European institutions, and vertically, i.e., between Europe, the nation-state and the regions-will only be able to succeed if Europe is established anew with a constitution. In other words, through the realisation of the project of a European constitution centred around basic, human and civil rights, an equal division of powers between the European institutions and a precise delineation between European and nation-state level."
} 
federalist hopes that such an endeavor would "catalyze" the emergence of a vibrant European demos. ${ }^{30}$ Although the Council tasked the Convention with finding ways to "increase the democratic legitimacy, transparency [and efficiency] of the present institutions" rather than fundamentally reconfiguring those institutions, ${ }^{31}$ the President of the Convention, Valery Giscard d'Estaing, was quick to define its task in Philadelphian terms. In his understanding, the Convention, preceded by a "listening phase" of consultations with citizens and civil society groups, was meant to do more than garner public engagement with the European project. As Giscard understood it, the Convention was meant to stage a "constitutional moment,"32 that is, to decisively shift the EU's basis of legitimation across the intergovernmental threshold into the domain of direct popular authorization.

Alas, the fruit of the Convention's labors, the equivocally entitled "Constitutional Treaty," was summarily rejected by the very demoi whose will it was intended to express, even if the referendum campaigns in France and the Netherlands were fought largely on issues other than the merits of the document itself. When the constitution-making enterprise ultimately fell short of its bombastic billing, the Philadelphian refrain that had accompanied its framing contributed not only to a deep sense of disappointment but heightened popular perceptions of the EU's democratic deficit. Meeting in 2007, the European Council commissioned a new intergovernmental conference to salvage the necessary institutional reforms from the wreckage of the Constitutional Treaty, and unceremoniously consigned the rest to the dustbin of history: "The constitutional concept, which consisted in repealing all existing Treaties and replacing them by a single text called 'Constitution,' is abandoned." 33

To many, the failure of this attempt at democratic constitution-making was hardly a surprise. In Weiler's words, "if there is no demos, there can be no democracy." 34 According to proponents of the "no-demos thesis," the EU does not generate a sufficient degree of political identification among citizens, and therefore lacks the necessary conditions of meaningful democratic engagement. ${ }^{35}$ Although supranational institutions constrain states or help to resolve well-defined policy problems, they lack the allegiance of "a group of people the vast majority of which feels sufficiently attached to each other to be willing to engage in democratic discourse and binding decision-making." ${ }^{36}$ On this view, domestic institutions still hold the key to political legitimacy and command the attention and loyalties of citizens, while "[n]either the Commission, nor the EP, nor the ECJ are understood to embody or express the capacity of a cohesive political community to rule itself

\footnotetext{
${ }^{30}$ Habermas, The Inclusion of the Other, 161

${ }^{31}$ European Council Presidency Conclusions, Laeken 14-15 December 2001, Annex I, pp.22-23, emphasis added.

${ }^{32}$ Bruce Ackerman, We The People. Foundations (Cambridge, MA: Belknap Press, 1991).

${ }^{33}$ Brussels European Council of 21-22 June 2007, Presidency Conclusions. 11177/1/07 REV 1, Annex I, I.1, p.15.

${ }^{34}$ Weiler, The Constitution of Europe, 337

35 e.g. Lindseth, Power and Legitimacy, 10

${ }^{36}$ Lars-Erik Cederman, "Nationalism and Bounded Integration: What it Would Take to Construct a

European Demos," European Journal of International Relations, vol.7 (2001), no.2, pp.139-74, 144
} 
through institutions historically constituted for that purpose." ${ }^{37}$ The absence of a vibrant and inclusive public sphere at the supranational level not only precludes the possibility of genuine constitutional rule taking root in the supranational context, ${ }^{38}$ but also ensures that attempts to impose a constitutional framework on the EU will result in an anti-European backlash. Pace Habermas, adherents of this view insist that the demos catalyzes the constitution, not the other way around. Without it, the EU's elaborate constitution-like characteristics cannot breathe democratic life into supranational politics. ${ }^{39}$

Since the attempt to reinvent the European Union as a supranational democracy by staging a Philadelphian moment failed, some of the certainty attending the use of constitutional terminology in scholarly debate has ebbed. Leading the charge, Peter Lindseth argues that it is a category mistake to describe the European Union in constitutional terms because:

"[t]he legitimation of supranational regulatory power (its 'mandate,' so to speak) has never been successfully located supranationally... Rather, it has been located, however tenuously, in the enabling treaties themselves, akin to enabling legislation on the national level, empowering the supranational exercise of regulatory discretion within the capacious limits defined by those treaties." 40

According to Lindseth, the fact that the EU is based on treaties ratified by member states to jointly govern matters of common interest means that it derives its legitimacy from democratic mechanisms at the domestic level, much as the moon borrows its light from the sun. By contrast, constitutional authority originates in the will of the people; it is original rather than derivative. As the failed Constitutional Treaty demonstrated, there is no pouvoir constituant behind the European Union's legal order; instead, its validity derives from the assent of member states and special provisions contained in national constitutions. Therefore, member states retain the sole true claim to the title "constitutional," while the EU's authority is more accurately understood as an extension of the postwar administrative state that complements representative democracy at the domestic level. ${ }^{41}$

Lindseth is surely correct to observe that supranational governance operates largely in the administrative mode: the EU's powers have been delegated to it by the

\footnotetext{
${ }^{37}$ Lindseth, Power and Legitimacy, 28

38 Dieter Grimm, “Does Europe Need a Constitution?", European Law Journal, Vol.1, No.3, 1995, pp. 282-302

${ }^{39}$ Habermas's idea of the "catalytic constitution" espouses something like a Haasian "spillover" logic: it assumes that the legal procedural model so created will be incrementally filled in by democratic substance. Insofar as the theory of constitutionalism that underpins what I have termed the democratic objection draws (among others) on Habermas's own work, it also exposes a fundamental tension between Habermas's political philosophy and his stance on the constitutionalization of the European Union. As John McCormick puts it, "Habermas resorts to an unsubstantiated historical narrative and an unreflective ideational construction of the past in comparison with/in contrast to the present so that the present might be grasped more facilely. That Habermas engages in such moves to highlight optimistic rather than Weberianly pessimistic possibilities does not mitigate the undertheorized quality of the moves themselves." John P. McCormick, Weber, Habermas, and Transformations of the European State. Constitutional, social, and supranational democracy (Cambridge: Cambridge University Press, 2007), 180

40 Lindseth, Power and Legitimacy, 19

41 ibid, 89
} 
elected representatives of member states; it exercises partially autonomous authority within functionally specialized areas of policy; its decision-making processes privilege technical expertise over partisan bargaining and impartiality over ideology; and it operates at arm's length from majoritarian control. In similar vein, Giandomenico Majone considers the EU's supranational elements as a continuation of domestic non-majoritarian institutions such as constitutional courts, central banks, and specialized regulatory agencies. ${ }^{42}$ While acknowledging that the European Union possesses greater political power and significance than Majone seems to allow, Lindseth insists that "supranational institutions remain administrative, not constitutional." 43

Although the Convention has dealt a severe blow to the attempt to impose a model of democratic constitutionalism onto the EU, abandoning constitutional terminology altogether in favor of an administrative model is also unconvincing. Several important features of the EU's complex institutional landscape militate against understanding administrative and constitutional modes of authority as a binary. ${ }^{44}$ Since very early on in the history of European integration, the power exercised by supranational institutions has outpaced their formal legal mandate, straining the principal-agent relationship implied by the administrative model. The flexibility of the treaties, the European Court's maximalist interpretations, and the wide scope and high stakes of supranational decision-making authority make it problematic to apply the same model of governance to the EU as one would to a telecommunications commission.

Thus, on the one hand, to the extent that the EU relies on technocratic competence and attenuated forms of democratic oversight for its legitimation, it resembles the administrative governance paradigm. On the other hand, its competences and scope of authority are too complex and extensive to subsist on circuits of borrowed democratic legitimacy, supplied for the most part by mechanisms of electoral accountability located at the domestic level. Viewed in terms of the significance of the governance tasks entrusted to it, as well as of the institutional devices it uses to hold member states to their commitments, the EU is more usefully thought of as constitutional. The concept of functional constitutionalism I develop in this chapter offers a way of registering the obsolescence of the distinction between administrative and constitutional modes of authority within the context of the European Union, while accounting for the problems of legitimation left in its wake.

\footnotetext{
42 Majone, "From the Positive to the Regulatory State," 153; Giandomenico Majone, "The Rise of the Regulatory State in Europe," Journal of Public Policy, vol.17 (1994), no. 3, pp.77-101, 84, 92; Majone, The European Community: An 'Independent Fourth Branch of Government'?,

43 ibid, 53

${ }^{44}$ It is also possible to question this binary on a conceptual level. As William Eskridge Jr. and John Ferejohn develop the idea of "administrative constitutionalism" in the US context, whereby a variety of statutory mechanisms, including administrative agencies, fulfill a constitutional role by fleshing out lofty constitutional commitments in the regulatory domain and thereby supplementing what the authors describe as the US's "old," vague, and incomplete "Large 'C' Constitution." See Eskridge and Ferejohn, A Republic of Statutes, esp. pp. 4-5.
} 
In light of these considerations, the rest of the chapter makes two argumentative moves. The first is to highlight the important respects, beyond the formal juridical characteristics outlined above, in which the EU does conform to conventional expectations of a constitutional regime. The second move is the reverse of the first: it is to highlight the important respects in which the legal order of the EU suspends, modifies, or qualifies the traditional expectations of constitutional rule. In particular, the supranational legal order breaks with the threefold assumption that constitutional authority must be comprehensive, exclusive, and fully autonomous, and instead exerts a form of authority that is functionally specialized, pluralistic, and only partially autonomous.

Taken together, these twin analytical moves are intended to show that the EU introduces a recognizable variation on the idea of constitutional rule, one that I term functional constitutionalism. Beyond giving an interpretive account of the EU legal order, this proposed sub-category is an attempt to detach the idea of constitutionalism from the background condition of a sovereign state. The European Union's legal system has already accomplished this in practice, but constitutional theory has yet to catch up. An alternative understanding of constitutionalism is therefore long overdue.

\section{(i) Why constitutional?}

Interestingly, while critics have rightly characterized Giscard's appeal to a Philadelphian narrative of popular constitution-making as a model for the EU as misguided, they have justified their critique by using the very same narrative. What remains to be questioned, however, is whether the Philadelphian narrative is the right frame for critically engaging with the EU. Without questioning the normative desirability of a democratic conception of constitutionalism, I will enumerate the reasons why constitutionalism is nevertheless the only apposite category for the entity that the EU has become. I also will not contest the proposition that the EU has been conceived and created by member states as a scheme of delegated authority, nor will I claim that it has hoodwinked them into surrendering the mantle of sovereignty, much less that the EU now wears that mantle. What I will argue is that the European Union is not or no longer usefully imagined as a discrete tier of governance that floats above national governments or as a forum for coordination among them; it has become deeply enmeshed with domestic institutions through a process of state transformation. ${ }^{45}$

In the previous chapter, I contended that unlike natural categories, social science concepts are historically contingent and politically conditioned. Concepts such as constitutionalism, democracy, or citizenship cannot simply be taken off a shelf, since they are thoroughly conditioned by the political and institutional forms that instantiate them. For this reason, any attempt to use them in a novel context cannot simply be an exercise in application, but must involve conceptual

${ }^{45}$ Christopher J. Bickerton, European Integration. From Nation-States to Member States (Oxford: Oxford University Press, 2012), 
adjustment. Having emerged against the background of the sovereign, territorial state, the concept of constitutionalism retains its imprint. Transplanting the Philadelphian narrative of constitutional rule in the supranational context in either a critical or aspirational vein is therefore tantamount to treating a social science category like a natural, unchanging one.

In response to this problem, I proposed an alternative approach to the definitional question, which was to contextualize the idea of constitutionalism by examining the major justificatory discourses that have shaped and sustained its modern practice. That exercise revealed that while democratic self-rule is one of the most important purposes associated with constitutionalism, it is not the only one. The fact that democracy often requires a constitutional framework to function does not mean that all constitutional systems are necessarily democratic. One can argue that the most legitimate, most desirable, or most stable constitutional systems are those that establish the strongest links between the exercise of political power and the will of the demos, but it is unpersuasive to move from this normative claim to a definitional one. The machinery of constitutionalism can be deployed to advance a wide range of teloi beyond that of democratic self-rule. For instance, a spate of recent scholarship attends to the ways in which constitutional rule has been used to thwart popular will, undermine individual rights, or perpetuate illiberal or hegemonic practices. ${ }^{46}$

Seen in this light, the no-demos thesis is correct that the EU does not conform to the democratic model of constitutional rule, according to which the authority of a constitutional system derives from the will of a self-governing demos. A legal system that does not establish a close enough correspondence between the will of the people as expressed through democratic procedures that the laws that bind citizens fails to meet this criterion. If citizens cannot regard the constitution as the expression of the collectively agreed terms of their union, they can regard it as an "imperial yoke" that stifles their civic autonomy. ${ }^{47}$ Each of these are meritorious grounds for critiquing the European Union's legal system. Despite its normative appeal, however, the democratic model of constitutional rule that informs the nodemos thesis captures only one of the many possible sources of constitutional authority. Such alternative sources include principles of natural or scriptural justice, appeals to the antiquity, custom, and inherited political structures, or arguments about stability and public order, each of which can provide justifications for elevating certain fundamental norms above democratic control. Seen in this light,

\footnotetext{
${ }^{46}$ Alexander Somek, "Authoritarian Constitutionalism: Austrian constitutional doctrine 1933 to 1938 and its legacy," in Christian Joerges \& Navraj Singh Ghaleigh (eds), Darker Legacies of Law in Europe (Oxford: Hart, 2003); Tom Ginsburg and Alberto Simpser (eds), Constitutions in Authoritarian Regimes (New York: Cambridge University Press, 2013); Turkuler Isiksel, "Between Text and Context: Turkey's tradition of authoritarian constitutionalism," International Journal of Constitutional Law 11:3 (July 2013), pp.702-26. On the role of judicial review in authoritarian contexts, see Tamir Moustafa and Tom Ginsburg, "Introduction: The Functions of Courts in Authoritarian Politics," in Tom Ginsburg and Tamir Moustafa (eds), Rule by Law: The Politics of Courts in Authoritarian Regimes (New York: Cambridge University Press, 2008)

47 James Tully, Strange Multiplicity: Constitutionalism in an age of diversity (Cambridge: Cambridge University Press, 1995), 5
} 
the no-demos thesis is essentially a normative claim that the EU is a bad constitutional system because it fails to meet the democratic standard of constitutional legitimacy. What it does not establish is that the EU should not be considered in constitutional terms at all.

There are two reasons why reserving the term "constitution" for documents that emerge through acts of popular self-constitution is overly restrictive. First, although democratic constitution-making is a fine ideal, as an empirical matter, it is a criterion that few existing constitutional orders can meet. More fundamentally, it is not clear that the democratic quality of a constitution hinges on whether it was drafted and ratified through processes involving high levels of popular participation (such as referenda, constituent assemblies, social mobilization, revolutionary upheavals, and the like). A constitutional regime imposed by a foreign power or a hegemonic elite can evolve into a democratic one if it puts into place effective and inclusive mechanisms of electoral representation, sets forth meaningful procedures of constitutional amendment, and garners popular engagement and allegiance (the Grundgesetz is a good example).

Second, viewing the constitution as the expression of the sovereignty of the people reflects the statist cast within which the constitutional ideal has evolved. Viewed as an expression of popular sovereignty, constitutional authority must be comprehensive, exclusive, and autonomous: comprehensive because all exercises of political authority within a given body politic ought to be subject to the terms of the constitution; exclusive because the constitution cannot derive its authority from any other legally constituted source; and autonomous because the will of the people is subject to no other source of authority. Under this conception, there is no clear distinction between sovereign and constitutional authority; the former is stipulated as a necessary condition of the latter.

If a constitutional order expresses the exclusive sovereignty of a political community, the European Union clearly cannot be considered a constitutional system. However, its member states also seem to increasingly fall short of that precondition. The assumption of a world made up of discrete, self-contained and self-validating constitutional orders is no longer a comprehensive description of empirical reality if it ever was. ${ }^{48}$ It is increasingly difficult to trace the authority exercised by global governance institutions to a single, comprehensive jurisdiction or to any single "metaprinciple of authority." ${ }^{9}$ In fact, the term "governance" itself, in contrast to "government," conveys uncertainty as to who or what is doing the governing. Contemporary legal systems both domestic and transnational are linked

\footnotetext{
48 It has been argued that it was not. For a representative sampling of the reasons why, see especially the contributions in Hent Kalmo and Quentin Skinner (eds), Sovereignty in Fragments. The Past, Present and Future of a Contested Concept (New York: Cambridge University Press, 2010). Also see Krasner, Sovereignty. Organized Hypocrisy; Lauren Benton, A Search for Sovereignty: Law and Geography in European Empires, 1400-1900 (New York: Cambridge University Press, 2010); Anthony Anghie, "Finding the Peripheries: Sovereignty and Colonialism in Nineteenth Century International Law," Harvard International Law Journal, vol.40 (1999), pp.1-81

${ }^{49}$ Neil Walker, "Beyond Boundary Disputes and Basic Grids: Mapping the Global Disorder of Normative Orders," International Journal of Constitutional Law, vol.6 (2008), no.3-4, pp. 373-396, at 376
} 
to one another in a myriad of ways: sovereign states are subject to jus cogens norms and accommodate competing claims raised from within other jurisdictions; ${ }^{50}$ they enter into mutual obligations under public international law; they abide by the judicial principle of comity and assume private and public law obligations to private actors such as business corporations; constitutional ideas cross-pollinate among different systems. ${ }^{51}$ In extreme cases, the writ of the constitution may no longer be enough to establish the authoritativeness of a particular rule; rather, national constitutions might need to stake their claim to validity among other competing systems and forms of law. Even within the domestic context, therefore, the paradigm of comprehensive, exclusive, and fully autonomous constitutional authority is no longer adequate. ${ }^{52}$ Much less can it capture the forms of constitutional rule that many contemporary international regimes practice without claiming the attribute of sovereignty.

Once we distinguish between sovereign and constitutional authority, by contrast, we no longer have to think of the EU as either an emanation of domestic legal systems or as sovereign over them. As Cohen observes, "[t]he non-derivative character of legal supranationalism is as important to grasp as the non-derivative character of domestic constitutions," not least in order to illuminate real shifts in normative authority that unconditional or absolutist conceptions of sovereign power tend to occlude. ${ }^{53}$ The constitutional perspective, shorn of its sovereigntist cast, captures a greater variety of legal form and function.

From a different quarter, critics have decried the inflationary use of constitutional terminology in relation to international institutions, particularly economic ones, as giving these institutions an aura of legitimacy that they otherwise lack. ${ }^{54}$ This is an important critique, but it cuts both ways. Describing the European Union as a constitutional places it under a greater burden of legitimation, because it captures the expansive scope of its power in comparison to less consequential political forms. By contrast, casting it as an international organization or an administrative agency understates the highly political nature of the decisions made at the supranational level. Put differently, describing a polity as constitutional does not let it off the hook in normative terms; to the contrary, it is a reminder that it must be held to a higher standard of legitimacy. As Michel Rosenfeld writes, it is "more profitable... to note the constitutional defects" of governance in the European Union "in comparison with the allocation of powers in a well-functioning nation-

\footnotetext{
${ }^{50}$ For a theory of the dense subterranean links between domestic constitutional norms and norms that are thought of as being external to the domestic order, see Jeremy Waldron, "Partly Laws Common to All Mankind": Foreign Law in American Courts (New Haven: Yale University Press, 2012).

${ }^{51}$ Sujit Choudhry (ed.), The Migration of Constitutional Ideas (Cambridge: Cambridge University Press, 2007)

52 MacCormick, Questioning Sovereignty, esp. ch.8

${ }^{53}$ Jean Cohen, "Sovereignty in the context of globalization: a constitutional pluralist perspective," in Samantha Besson and John Tasioulas (eds), The Philosophy of International Law (Oxford: Oxford University Press, 2010), at 273

${ }^{54}$ Robert Howse and Kalypso Nicolaidis, "Legitimacy through 'Higher Law'? Why constitutionalizing the WTO is a step too far," in Thomas Cottier and Petros C. Mavroidis (eds), The Role of the Judge in International Trade Regulation: Experience and lessons for the WTO (Ann Arbor: University of Michigan Press, 2003)
} 
state parliamentary democracy from a critical constitutional standpoint than from a perspective that stipulates that the ideals of constitutionalism are inapposite when considering the EU." 55 Not only do we risk more by shying away from constitutional terminology than by using it, but we also miss an important opportunity to think about how constitutionalism may look beyond its statist cast.

Perhaps most important of the considerations that speak in favor of taking the EU's constitutional features seriously is that however else it may be defined, a constitutional system is constitutive; it lays the foundations of a political community. To be sure, the EU appears at first glance to be an addendum to the state system since it rests on a nexus of revocable agreements among states. Besides, at no point in its history has any member state announced any intention to relinquish its primacy as a political unit to the European political order. Still, this definition of what counts as a constitutive order contains remnants of an eighteenth century revolutionary imaginary, according to which a constitutive act must be one that dramatically sweeps away of the ancien regime and replaces it with a novus ordo saeclorum. In practice, however, radical constitutional shifts tend to occur in an evolutionary, rather than revolutionary, manner. When, precisely, did the American states cease to be sovereign, or agree to such cession? When did Britain become a democracy? When did Russia stop being one? When did France revert to being a nation-state rather than an empire? In each case, it is clear that a constitutive shift has occurred in the nature of political community, but it is artificial, not to say counterfactual, to assign a revolutionary watershed to each. Similarly, European integration has engendered a transformation that is of constitutional scale, no less for its incremental trajectory and lack of an eponymous document. As Craig writes, the EU legal order has evolved from "a relationship binding upon the states qua states, to an integrated legal order that confers rights and obligations on private parties, and one in which the controls on the exercise of public power are similar in nature to those found in nation states."56

Having been called into existence by sovereign nation-states, the European integration project has fundamentally reconstituted them in turn. The EU's constituent units have not ceased to be states, but they have become member states, which Bickerton characterizes as a "distinctive kind of state where national power is exercised in concert with others" and "whose self-understanding is inseparable from pan-European-level cooperation." 57 Much as marriage transforms two unattached individuals into members of a new social unit, EU membership has led states to "understand their power and identity as dependent upon their belonging to a wider group or community." 58 EU law is constitutive not only in the sense of establishing a supranational institutional and normative structure, but also in the sense of having occasioned far-reaching institutional, legal, social, political, and cultural transformations within its member states. Prompted most recently by the

\footnotetext{
55 Michel Rosenfeld, “Is Global Constitutionalism Meaningful or Desirable?", European Journal of International Law, forthcoming.

${ }^{56}$ Paul Craig, "Constitutions, Constitutionalism, and the European Union," European Law Journal, vol.7 (2001), no.2, pp.125-50, 128.

${ }_{57}^{57}$ Bickerton, European Integration. From Nation-States to Member States, 4,49

${ }^{58}$ Ibid., 12. The marriage metaphor is mine.
} 
euro crisis, member states have candidly acknowledged that rolling back this prominent feature of European integration would not simply break a supranational agreement, but would scramble all aspects of their domestic social and economic circumstances.

As a composite polity that is embedded within member states as much as it is above them, the EU not only shapes the domestic and international policy options available to member states, but has also profoundly altered their domestic constitutional systems. ${ }^{59}$ EU law weaves together supranational, national, and subnational norms and applies sophisticated tools to smooth the resulting snags. ${ }^{60}$ Supranational governance in Europe is constitutive because it creates a new configuration of political authority all the way down. While none of the transformations occasioned by European integration are irreversible, much less inevitable, they are extensive and significant. In other words, they are constitutive in nature.

\section{(ii) Why "functional"?}

As I argued in the previous chapter, the higher order norms that constrain, shape, and regulate the exercise of political power may be justified in a variety of ways. Unlike most contemporary constitutional systems, the authority of the EU legal order does not rely on a democratic pattern of justification. Rather, it rests on a claim to enable the effective exercise of public power in policy areas designated by the member states. Far from being a novel claim of constitutional legitimacy, this

\footnotetext{
59 To point out some well-known examples: In the Simmenthal II case of 1978, the ECJ authorized lower courts to invalidate domestic statute in the event of a conflict with European law, thereby overriding the Italian Constitution's prohibition against judicial review by lower courts. See Case 106/77, Amministrazione delle Finanze dello Stato v. Simmenthal SpA [1978] ECR 629. In its 1996 Factortame judgment, the ECJ arguably went further. As Mitchell Lasser describes it, the ECJ held that "the 'full, effective judicial protection' of Community rights justifies overriding the most basic premises of national constitutional law and separation powers doctrine: it requires Member State courts to overturn national legislation that is incompatible with - and therefore represents an 'obstacle' to - Community law, even in those legal systems that do not grant such powers of review to their judiciaries." (Lasser, Judicial Deliberations, at 225; Joined cases C-46/93 and 48/93, Brasserie du Pêcheur SA v Bundesrepublik Deutschland and The Queen v Secretary of State for Transport [1996] ECR I-1029, para.33) The British House of Lords, who had sent the original reference to the ECJ, accepted that the UK's membership in the EC necessitated the recognition of the supremacy of Community law, which in turn required curtailing the implied repeal (lex posterior) doctrine which had hitherto been the cornerstone of the British system of parliamentary sovereignty. See House of Lords, Factortame Ltd. and others v. Secretary of State for Transport [1991] 1 AC 603. Also see Miguel Poiares Maduro, "The importance of being called a constitution: Constitutional authority and the authority of constitutionalism," International Journal of Constitutional Law, vol.3 (2005), no.3, pp.332-356, at 339340

60 In the present work, I set aside the question of whether the EU counts as a federal state, a federal non-state, or a confederation. On this question, see Jean Cohen's compelling theory of the federation understood "as a union of states and peoples" that is not itself a state, which draws on the structure of the European Union and Olivier Beaud's conception of federalism. See Jean Cohen, Globalization and sovereignty. Rethinking legality, legitimacy and constitutionalism (New York: Oxford University Press, 2012), 85, and ch.2 more broadly.
} 
pragmatic pattern of justification has its roots in some of the earliest instances of sovereign commitment. The primary purpose for which constitutional rules are valued may be that they enable the state to perform various tasks it might otherwise be hampered from doing, such as securing cheap credit, encouraging private industry, or pacifying sectarian struggle. Unlike the democratic pattern of justification, furthermore, the pragmatic logic is perfectly compatible with composite and multi-leveled forms of political ordering. I will highlight three elements of the EU's legal order, including its functional specialization, teleological fixity, and its emphasis on a claim to effective government as the key features that make this a distinctive model of constitutional rule, which I term functional constitutionalism. I will also explain why these elements distinguish functional constitutionalism from democratic and rights-based models that inform most existing constitutional surveys of the European Union.

First, however, we need to differentiate between several settled connotations of the term "functionalism" and the meaning I hope to convey by it. In the EU context, functionalism (or more accurately, neofunctionalism) is associated with a prominent but contested research program inaugurated and later critiqued by Ernst Haas. ${ }^{61}$ Though they come in many varieties, neofunctionalist accounts privilege the agency of supranational institutions and the shifting loyalties of grassroots political actors to explain the gradual transfer of sovereignty away from member states. ${ }^{62} \mathrm{As}$ a broader explanatory paradigm in social science, functionalist patterns of explanation assume that "specialized structures will evolve to perform new tasks or to fulfill new needs as these arise."63 My argument about functional constitutionalism does not aim to provide a causal hypothesis of this sort; it is not an investigation of the conditions that explain why the EU's legal system has evolved in the way that it has. Rather, it is an interpretive and critical account of a legal system that combines an array of familiar and novel constitutional features. I use the qualifier "functional" to convey a claim about the deeper pattern of legitimacy and purposiveness embodied by the EU's constitutional order. This is an exercise in excavating the ends and values sedimented into the EU's normative structure. For the most part, it remains agnostic on the question of which empirical factors might explain that particular pattern. It neither presumes nor challenges the empirical value of functionalist or neofunctionalist accounts of European integration.

Second, the language of functionalism and governmental effectiveness is substantively underdetermined. It does not specify what outcomes might count as effective government, and what the proper gauge for such judgments might be. I attempt to remedy this inevitable vagueness by distinguishing functionalist patterns

\footnotetext{
${ }^{61}$ Ernst B. Haas, The Uniting of Europe. Political, Social, and Economic Forces 1950-1957 (Notre Dame, Indiana: University of Notre Dame Press, [1958] 2004); and later, Ernst B. Haas, The Obsolescence of Regional Integration Theory (Berkeley: University of California Press, 1975). For a friendly overview of what is living and what is dead in neofunctionalist integration theory, see Philippe C. Schmitter, "Ernst B. Haas and the Legacy of Neofunctionalism," Journal of European Public Policy, vol.12 (2005), no.2, pp. $255-72$

${ }^{62}$ See especially, Haas, The Uniting of Europe, ch.1

${ }^{63}$ John Gerard Ruggie, "Collective Goods and Future International Collaboration," American Political Science Review, vol.66 (1972), no.3, pp.874-893, at 875
} 
of legitimation from democratic and rights-based patterns. Where a particular way of organizing the exercise of public power is justified with reference not to its conduciveness to individual liberty or to participatory government, but to the epistemic quality of the decisions made or their superior administration, we can say that a functionalist mode of legitimation is at work. Most such instances will make concrete reference to a certain telos to be achieved, such as wealth maximization, public order and safety, efficient use of scarce resources, or some other vector of the public interest. As important, functionalist justifications assume the existence of a truly public interest: typically, the outcome in question will be justified either as making everyone better off or, at least, leaving no one worse off.

The 1957 Treaty of Rome aimed to pursue one such outcome in particular through cooperation between member states: that of generating economic prosperity through market integration. ${ }^{64}$ Although the forces of "creative destruction" unleashed by market integration would inevitably make less competitive sectors worse off, the Treaty system offered many ways of compensating the disadvantaged, whether through cohesion funds, free movement of labor, agricultural subsidies, and the like. Over time, the European Union has amassed a formidable portfolio of policy competences, "[t]he enhanced effectiveness generated by the supranational regulation of transnational economic exchange," not to mention the benefits of a competitive, integrated, and expanding market in goods, services, and capital, "represents an important legitimizing function of supranationalism." 65 Put differently, the promise of economic prosperity, and a variety of public goods associated with an integrated marketplace, is the primary justification for the EU's claim to bind member states and their citizens. By way of contrast, consider that the existence of particular nation-states as political units is rarely justified in such a narrow, purposive manner: Swedes desire the continued existence of Sweden not predominantly because it makes them wealthier or safer or better administered than they otherwise would be, but because it best represents their political unity as a people. Although extreme economic circumstances may trigger separatist movements, states tend to command a much more wide-ranging discourse of justification than the functionalist discourse that sustains the European Union.

Third, particularly in the terminology of US comparative constitutional analysis, functionalism refers to an approach that accounts for variation among political institutions with reference to the problems or imperatives of governance to which they respond. ${ }^{66}$ Understood in this way, functionalism is an epistemic

\footnotetext{
${ }^{64}$ On the economic focus of EU law, see, among others, Miguel Poiares Maduro, We the Court: The European Court of Justice and the European Economic Constitution (Oxford: Hart Publishing, 1998); Christian Joerges and Michelle Everson, "Law, economics and politics in the constitutionalization of Europe", in Erik Oddvar Eriksen, John Erik Fossum, and Augustin Jose Menendez (eds), Developing a Constitution for Europe (London: Routledge, 2004).

${ }^{65} \mathrm{ibid}, 402$

${ }^{66}$ Mark Tushnet, "The Possibilities of Comparative Constitutional Law," Yale Law Journal, vol.108 (1999), no.6, pp. 1125-1309, 1238. For a critique of the functionalist approach, see Ruti Teitel, "Comparative Constitutional Law in a Global Age," Harvard Law Review, vol.117 (2004), no.8, pp. 25702596 (arguing that a functionalist analysis of constitutionalism is problematic insofar as "a shared understanding of the aims of constitutionalism... has not yet emerged." 2576)
} 
method, a tool of the knower rather than a feature of the known. By contrast, the term functionalism as it is used here is a guiding characteristic of the constitutional order itself, rather than an analytical tool with which to understand it.

Finally, I do not use the phrase functional constitutionalism to mean that the $\mathrm{EU}$ is a functional analog to a constitutional system, or to suggest that it approximates such constitutional features as a hierarchy of norms, a regime of individual rights, or a system of judicial review. I wish to argue both more and less than this: on the one hand, my claim is that the EU is not simply analogous to a constitutional regime; it is a particular kind of constitutional regime. On the other hand, I wish to go beyond establishing resemblances between domestic and supranational constitutional practice, and use the term "functional" to convey the latter's distinctive features.

Having pointed out what I do not mean by describing the EU as a system of functional constitutionalism, let me move on to a positive articulation of the argument. To my mind, this phrase captures three distinctive elements of the EU's legal order. The first of these is that unlike domestic constitutions, which govern the full spectrum of public power within the body politic, the EU's legal order is functionally specialized. Second, it is framed around a specific set of objectives having to do with market integration; that is to say, it espouses a relatively narrow teleology that is insulated from revision. Third, its legitimacy depends on the successful realization of those substantive objectives; that is to say, its basis of legitimacy is functionalist rather than democratic. I will discuss each of these characteristics in turn.

\section{Functional specialization}

In the context of the sovereign state, constitutionalism represents a comprehensive system of validation for public authority. Put differently, all exercises of state power must filter through the mesh of constitutional validity, or, as Grimm writes, that "[t]here is no space for proprietors of public power outside the constitution." 67 Not only is the constitution the highest authority in a legal order, but it also has what Frank Michelman terms a "pervasive" quality. ${ }^{68}$ Exertions of public power are valid insofar as they fall within the realm of possibility opened up by the constitution.

In contrast to this comprehensive conception of constitutional authority, the decisions of EU institutions bind member states and their citizens only within the scope of powers explicitly conferred to the EU by the member states. Even though its boundaries remain fuzzy, the EU's area of competence covers a functionally interrelated cluster of public policy objectives. Of the senses in which the term "functional constitutionalism" captures the distinctive characteristics of the EU's

${ }^{67}$ Dieter Grimm, "Treaty or constitution? The legal basis of the European Union after Maastricht," in Erik Oddvar Eriksen, John Erik Fossum, and Agustín José Menéndez (eds), Developing a Constitution for Europe (New York: Routledge, 2004), at 72

${ }^{68}$ Frank I. Michelman, "What do constitutions do that statutes don't (legally speaking)?", in Richard W. Bauman and Tzvi Kahana (eds), The Least Examined Branch: The Role of Legislatures in the Constitutional State (Cambridge: Cambridge University Press, 2006) 
legal order, then, the first is the fact that its scope of authority is functionally circumscribed rather than comprehensive.

Since supranational law cannot lay claim to comprehensive validity traditionally associated with constitutional rule, its authority is coupled with an implicit recognition that other constitutional orders are responsible for other sectors of public authority. Thus, on the one hand, EU law claims supremacy over national law in the way that constitutional norms prevail over ordinary statute within domestic constitutional systems. Furthermore, the CJEU has interpreted the supremacy principle as an unconditional one, holding that even domestic constitutional norms must give way if they conflict with EU law. 69 "As a consequence of the supremacy of European law, the four economic freedoms, and the injunctions against distortions of competition, have in fact gained constitutional force vis-à-vis member states." 70

On the other hand, however, supranational law has primacy over national laws only within the sphere of validity delineated by the founding treaties, in other words, within a functionally delimited area of public policy. Even within that scope, moreover, EU law is subject to occasional pushback from domestic judiciaries, and relies on national courts for its application. ${ }^{71}$ As a result, the EU legal order is only partially autonomous, since any significant expansion of its authority must be ratified by member states and can be reduced by them. ${ }^{72}$ Furthermore, whereas domestic constitutional documents rarely contain provisions delimiting their normative authority, the treaties that ground the EU's supranational authority contain many expressions of this sort. ${ }^{73}$

In this respect, functional constitutionalism also differs from a typical federal constitutional system. Like many federal systems, the EU operates on the basis of a principle of enumerated or conferred powers; that is, it can only act on matters explicitly entrusted to it. Furthermore, like many federal systems, the vertical allocation of competences between the EU and its member states follows a functional pattern: some areas are exclusively entrusted to the EU; other policy decisions require coordination between the EU and member states; and a third category is reserved to states alone. Unlike the EU's legal system, however, the scope of a federal constitution's authority is typically of comprehensive, rather than functionally delimited, scope. Public institutions at all levels draw their authority

\footnotetext{
${ }^{69}$ Fritz Scharpf, Governing in Europe: Effective or Democratic? (Oxford: Oxford University Press, 1999), 54; Case 106/77, Amministrazione delle Finanze dello Stato v. Simmenthal SpA [1978] ECR 629; Case C-213/89, The Queen v Secretary of State for Transport, ex parte: Factortame Ltd and others [1990] ECR I-2433

${ }^{70}$ ibid, 58

${ }^{71}$ Miguel Poiares Maduro, "Europe and the Constitution: What if this is as Good as It Gets?", in J.H.H. Weiler and Marlene Wind (eds.), European Constitutionalism Beyond the State (Cambridge: Cambridge University Press, 2003), 93

${ }^{72}$ Art 48 (2) TEU.

${ }^{73}$ Art 1(1) of TFEU reads: "This Treaty organizes the functioning of the Union and determines... the delimitation of... its competences." In addition, Article 2(6) TFEU provides that "The scope of and arrangements for exercising the Union's competences shall be determined by the provisions of the Treaties relating to each area," meaning that each Treaty competence contains the terms of its own limitation.
} 
from the constitution, even if the federal government itself is relatively weak vis-àvis constituent units. In a typical federal system, then, the federal constitution is still the ultimate measure of legal validity. By contrast, functional constitutionalism is a system of limited material scope; it acknowledges that other legal systems take precedence in policy matters not allocated to it. In policy areas that exceed its functionally defined scope of authority, the functional constitution acknowledges that it is not the supreme law.

By acknowledging the limits of its own scope of application, yet operating as a fully-fledged constitutional system within that scope, the European Union's legal order effectively detaches the constitutional form of political ordering from the attribute of sovereignty. Although one could construe the relationship between the EU's legal order and the constitutional systems of its member states as one of suband superordinate, derivative and original authority, it simply is not very instructive to do so. Rather than trying to shoehorn these complex relationships into a neat hierarchy, it is more useful to trade in the monistic conception of constitutional authority in favor of a "pluralist [and dispersed] conception" in which "different persons or bodies having the power to decide in different circumstances, without there necessarily being any single, hierarchical system of decision-making." ${ }^{4}$ Constitutional autonomy in Europe's contemporary legal landscape is more helpfully conceived as graduated and intersectional rather than exclusive and comprehensive.

To be sure, the picture I have painted here differs from the respective perceptions of both domestic constitutional courts and the EU judiciary of Europe's legal landscape and their own position within it. The Court of Justice famously claims exclusive authority to adjudicate the bounds of supranational legal authority, and has held that "national courts have no jurisdiction themselves to declare that measures taken by Community institutions are invalid."75 Leading the countercharge on the part of national judiciaries, the German Federal Constitutional Court reserves to itself the right to "[examine] whether legal instruments of the European institutions and bodies keep within the boundaries of the sovereign powers accorded to them by way of conferral," that is, to conduct ultra vires review of EU acts where the EU judiciary fails to do so. ${ }^{76}$ In a pluralist constitutional landscape, it is not surprising that questions of autonomy, supremacy, and decisional finality will garner competing, even incommensurable answers from the point of view of each legal order. The perspective of the observer, however, need not overlap with that of any single participant. The task of constitutional theory is to comprehend the claims of constitutional primacy raised by member state courts and the EU judiciary on their own terms, though without necessarily buying into any of them.

\footnotetext{
${ }^{74}$ Richard Bellamy and Dario Castiglione, "Building the Union: The Nature of Sovereignty in the Political Architecture of Europe," Law \& Philosophy, vol.16 (1997), no.4, at 422

${ }^{75}$ Case 314/85, Foto-Frost v Hauptzollamt Lübeck-Ost [1987] ECR 4199

${ }^{76}$ German Federal Constitutional Court, Order of 30 June 2009, 2 BvE 2/08 (German Lisbon Decision), para.240. English translation available at http://www.bundesverfassungsgericht.de/SharedDocs/Entscheidungen/EN/2009/06/es20090630 2bve0002 08en.html
} 
In response to periodic challenges to the supremacy of supranational law by domestic constitutional courts, the Court of Justice has cultivated an instructive jurisprudence of what Weiler terms "constitutional toleration" or "constitutional conversation."77 Constitutional toleration is a discursive practice among the epistemic community of European jurists that enables a plurality of relatively autonomous orders to accommodate one another's claims to validity. As Weiler writes, "the constitutional discourse in Europe must be conceived of as a conversation of many actors in a constitutional interpretive community rather than a hierarchical structure with the ECJ at the top," and in which "the jurisdictional line (lines) should be a matter of constitutional conversation, not a constitutional diktat."78 This reciprocal practice engages domestic judiciaries in resolving questions about Europe's complex constitutional architectonic, and illustrates the dialectic process by which the EU's legal system has come to be been embedded within domestic constitutional orders, while prompting domestic constitutional orders to adapt to supranational obligations. A Manichean distinction between sovereign constitutional authority held by member states, and delegated authority held by the European Union is ill-suited to capturing this dynamic process of reciprocal reconstitution.

By contrast, functional constitutionalism is better adapted to describe a system that is "layered around already existing orders so that the result is an increasingly compound and accumulated executive order."79 The functional constitution is neither subordinate nor superordinate vis-à-vis the local, regional, or national levels of law; rather, it carves out a composite slice of local, subnational, and national tiers of governance on the basis of a particular policy area. It is neither unambiguously subordinate nor superordinate vis-à-vis any of those levels taken individually. What I refer to throughout this book as the EU legal order is, fundamentally, a European legal order; one that encompasses not just a framework of supranational law but also national legal orders insofar as they intersect with the scope of EU competence. This distinctive configuration is nicely encapsulated by John McCormick's term "Sektoralstaat," according to which "the EU is a qualitatively different and new form of polity" in comparison with either the law-governed liberal state (Rechtsstaat) of the early $20^{\text {th }}$ century or the corporatist welfare state (Sozialstaat) of the postwar period. ${ }^{80}$ The concept of the Sektoralstaat denotes the simultaneous aggregation of levels of governance around a particular policy issue and the disaggregation of public power into "functionally limited enumerated powers." 81 Constitutional mechanisms of entrenchment, supremacy, and direct effect help to insulate these enumerated powers against interference from national democratic control or constitutional scrutiny. As McCormick argues, supranational governance in Europe represents the emergence of a sectorally concentrated form

\footnotetext{
77 J.H.H. Weiler, "European Neo-Constitutionalism: In Search of Foundations for the European Constitutional Order", in Political Studies, vol.44 (1996), no.4, pp.517-533

78 ibid, 532

79 Deirdre Curtin and Morten Egeberg, "Tradition and Innovation: Europe's Accumulated Executive Order," West European Politics, vol.31 (2008), no.4, pp.639-661, 640

80 McCormick, Weber, Habermas, and Transformations of the European State, 250

${ }^{81}$ Mestmäcker, "On the Legitimacy of European Law," 633
} 
of authority that is administered through its own logics of coordination. In particular, whereas the Rechtstaat was animated by the principle of the rule of law and limited government, and the Sozialstaat by the principle of solidarity, the Sektoralstaat has its own animating principles, namely those of expediency and epistemic competence. I discuss these principles in section (3) below.

Perhaps the most important contribution of the EU's supranational legal system to our social scientific conception of constitutionalism, then, is a demonstration of the possibility (as distinct from the desirability) of constitutional pluralism in which distinct legal systems exercise complementary and occasionally conflictual forms of authority. Just as Diogenes the Cynic is fabled to have disproved Zeno's dichotomy paradox by standing up and walking the distance that in theory should be impossible to cross, the EU bears out what a sovereigntist conception of constitutionalism dismisses as impossible, namely, a pluralist system of constitutional authority in which "[d]istinct systems can co-exist without any one having to deny either the independence or the normative character of another." ${ }^{82}$

\section{Teleological rigidity}

Constitutional theorists often distinguish constitutional norms from ordinary legislation on the basis of two spectral characteristics: first, relative to ordinary legislation, constitutional norms tend to be more onerous to modify. In this vein, Holmes and Sunstein argue that "[c]onstitutionalism hinges upon a distinction between the procedures governing ordinary legislation and the more onerous procedural hurdles that must be overcome in order to recast the ground rules of political life." 83 In particular, the constitution's function as the normative frame for politics implies that, all things equal, it should be resistant to abrupt alteration and partisan manipulation for short-term political gain. As Elster writes, constitutionalism "ensures that constitutional change will be slow, compared to the fast lane of ordinary politics." 84

Secondly, due in part to their relatively fixed status, constitutional norms are expected to be substantively more open-ended in comparison to ordinary legislation. If constitutional rules are onerous to change, they should be broad enough to accommodate a wide variety of political agendas and supple enough to countenance changing social circumstances. In differentiating constitutional rules from ordinary political rules, public choice theorists in particular tend to emphasize the former's relative indeterminacy towards alternate policy choices. The metaphor of a sporting competition is used to illustrate the difference: constitutional design is analogous to "agreements on the rules of a game" whereas the ordinary policy process seeks "agreements on the outcomes." 85 Put differently, "[a]t the

\footnotetext{
82 MacCormick, Questioning Sovereignty, 75

${ }^{83}$ Holmes and Sunstein, "The politics of constitutional revision in Eastern Europe," 275

${ }^{84}$ Elster, Ulysses Unbound, 100

85 Dennis C. Mueller, Constitutional Democracy (New York: Oxford University Press, 1996), 62
} 
constitutional stage, one chooses the institutions that will be used to make all future political choices." 86 Similarly, James Buchanan writes that "the hallmark of the constitutionalist is the categorical distinction he makes between outcomes generated within defined rules and the rules themselves."87

Taking this argument one step further, Dennis Mueller argues that the process of constitutional framing is likely to promote relatively neutral structural choices that allow for as many possible policy outcomes as possible. Provided they represent sufficiently diverse interests, Mueller hypothesizes that constitutional framers will look for rules that are unlikely to favor certain future substantive outcomes over others. ${ }^{88}$ Since framers will not be able to agree on, much less foresee, the full spectrum of substantive policy controversies that will arise in the future, they are expected to converge on rules that either reflect shared substantive values or set out procedures that are impartial (as far as possible) regarding future outcomes.

Mueller's assumption on this score seems overly sanguine. It is difficult to guarantee either the fairness or the impartiality of constitutional choice: at worst, the constitution-makers may be a privileged cabal looking to oppress and exploit the majority. Even if they are not, constitutions are invariably shaped by contingent bargains, existing power imbalances, and past injustices. Framers might converge on rules that help them entrench their existing advantages at the expense of excluded groups. As Ran Hirschl argues, constitutional entrenchment can be a tool for "hegemonic preservation" rather than for protecting universalizable interests. ${ }^{89}$ Constitutional norms can immunize the preferred policies of elites against future majoritarian challenge. In similar vein, Melissa Schwartzberg argues that as a historical fact, the strategy of making certain norms immutable has "a rich legacy of protecting narrow, instrumental decrees, such as treaties, and unjust laws against religious toleration and, most notoriously, slavery." 90 A constitutional norm, just like any other legal norm, can be unjust, oppressive, or illiberal; but in contrast to an ordinary legal norm, it is that much more difficult to change. Where constitutional rules diminish the ability of citizens to contest acts of domination, they deny rather than fulfill those promises that vindicate the legitimacy of constitutional rule.

Although it throws into doubt the tenability of the distinction between constitutional choice and everyday political choice, however, this line of critique nevertheless speaks in favor of reinforcing it in practice. Assuming, as Charles Beard contended with regard to the US Constitution, that the framers of a constitutional document are likely to have strong interests in designing the constitution so as to

\footnotetext{
86 ibid, 62

${ }^{87}$ Geoffrey Brennan and James M. Buchanan, The Reason of Rules. Constitutional Political Economy (New York: Cambridge University Press, 1985), 20

88 Mueller, Constitutional Democracy, 63. Also see James Buchanan and Gordon Tullock, The Calculus of Consent (Ann Arbor: University of Michigan Press, 1962)

${ }^{89}$ Ran Hirschl, "The Political Origins of the New Constitutionalism," Indiana Journal of Global Legal Studies, vol.11 (2004), no.1, pp.71-108. Also see Ran Hirschl, Towards Juristocracy: The Origins and Consequences of the New Constitutionalism (Cambridge, MA: Harvard University Press, 2004) ${ }_{90}$ Melissa Schwartzberg, Democracy and Legal Change (New York: Cambridge University Press, 2007), 25
} 
favor their own interests, ${ }^{91}$ constitutional norms should either be sufficiently mutable to allow the marginalized to seek revision in the future, or substantively open-ended in order to allow such contestation to take place at the level of the ordinary political process (or both). Put differently, since entrenched norms are a potential hegemonic device, it is all the more important to insist that constitutional norms be substantively underdetermined in the sense widening the spectrum of policy choices available to the ordinary legislative process. As Richard Bellamy argues, "rather than a resource of the fundamental answers to the question of how to organize a democratic society, the constitution represents a fundamental structure for reaching collective decisions about social arrangements in a democratic way." 92 Constitutional norms and practices that define the parameters of the democratic process must stop short of entrenching the mandated outcomes of those processes. The very compatibility of constitutionalism with ideals of individual liberty and participatory government hinges on the possibility of an analytical distinction between the rules and outcomes of the political process, and the constitution's ability to maintain that distinction in practice.

While no constitutional regime is indifferent with regard to outcomes, and the purest proceduralism is not free from substantive presuppositions, EU law largely collapses the very distinction between defining the rules of a game and stipulating the outcome of the game. ${ }^{93}$ The second sense in which I use the term "functional," then, is to describe the use of constitutional mechanisms as "an instrument for action" rather than as a "framework of political action." 94 Rather than laying down basic rules to govern the future selection of policy ends, EU law determines those ends with the kind of detail that would typically be left up to the ordinary legislative or administrative process. Thus, on the one hand, because EU law exists to hold states to their long-term policy commitments, it is far more detailed in mandating particular outcomes compared to most constitutional norms. On the other hand, both treaty provisions and ordinary EU measures are difficult to revise or repeal, requiring agreement among member states and, in some instances, ratification in accordance with domestic requirements. In curtailing the policy options available to domestic majorities, EU law does not only entrench the external obligations of member states, but reorders their internal priorities. Joerges notes, "the institutionalising of a European market order does not simply bear upon states' capacity for political action, but ultimately also on the states' own constitutional identities." 95

\footnotetext{
${ }^{91}$ Charles A. Beard, An Economic Interpretation of the Constitution of the United States (New York: Macmillan Company, 1921 [1913]).

92 Richard Bellamy, Political Constitutionalism: A Republican Defence of the Constitutionality of Democracy (Cambridge: Cambridge University Press, 2007), 4

${ }^{93}$ For a critique of proceduralist constitutional theory (in particular, that of John Hart Ely) on these grounds, see Lawrence H. Tribe, "The Puzzling Persistence of Process-Based Constitutional Theories", Yale Law Journal, vol.89 (1980), pp.1063-80

94 The distinction is Jon Elster's. He argues that a constitution should be thought of as the latter rather than the former. See Elster, Ulysses Unbound, 100, emphasis added.

${ }^{95}$ Christian Joerges, "Taking the law seriously: On political science and the role of law in the process of European integration," European Law Journal, Vol.2 (1996), No.2, pp. 105-135, 109
} 
Perhaps most importantly, the procedural rigidity of EU law is coupled with teleological rigidity; that is to say, not only are the various procedures for amending EU law onerous, but they also impose elaborate substantive obligations on member states. Whereas constitutions traditionally justify entrenched rules for their role in institutionalizing democratic revision and contestation, the EU's legal order has been configured to diminish the ability of member states and their citizens to revise their policy commitments. ${ }^{96}$ As Stefano Bartolini notes, "the constitutionalization of the treaties has 'frozen' certain specific goals by shielding them from political redefinition." ${ }^{\prime 97}$ To be sure, the treaty objectives are negotiated by electorally accountable member state governments and approved by national parliaments or subjected to popular referenda. Even if treaty objectives are ultimately traceable to the will of national publics, however, the entrenched status of the treaties makes downstream contestation and revision difficult. Supranational institutions such as the Commission, the Court, or even the European Parliament tend to work within the existing teleological parameters of the treaties. Unlike domestic political institutions, these bodies are purposive in their configuration: they can push the integration project forward, but not backward; they can expand it, but can do little to constrain it. This combination tends to create a one-way ratchet in favor of the objectives enshrined in the treaties, while narrowing the options available to democratically elected legislatures particularly at the domestic level. In sum, EU law is substantively elaborate in the way of ordinary legislation, but entrenched in the manner of constitutional law, creating an unusually rigid framework for the exercise of political authority.

\section{Functionalist basis of legitimation}

The most distinctive aspect of the European Union's constitutional system is its functionalist pattern of legitimation, a theme I have already discussed in outline. To recall, democratic theories of constitutional rule justify the authority of entrenched constitutional norms with reference to their role in enabling the exercise of popular self-rule. Likewise, under a liberal conception, constitutional guarantees deserve allegiance because they safeguard the sacrosanct liberties of individuals. Despite having many of the features of a constitutional system,

\footnotetext{
${ }^{96}$ Alan Milward famously argued that supranational delegation acts precisely to consolidate the nation-state's governing capacity. Neofunctionalist theories generally disagree with this premise, arguing that governing capacity has passed to supranational institutions, particularly executive and judicial ones. However, both sides appear to agree that the aim of European integration has been to enhance governing capacity, but disagree over how it affects the distribution of power between supranational, national, and sub-national levels. See Alan Milward, European Rescue of the Nationstate; also, Peter L. Lindseth, "The Contradictions of Supranationalism: Administrative Governance and Constitutionalization in European Integration since the 1950s," Loyola of Los Angeles Law Review, vol. 37 (2003), no. 2, pp.363-406

${ }^{97}$ Stefano Bartolini, Restructuring Europe. Center Formation, System Building, and Political Structuring between the Nation-State and the European Union (Oxford: Oxford University Press, 2005), 165
} 
however, the EU's authority over member states and their citizens is not justified primarily with reference to either of these principles. It is far more commonly justified on the grounds that it allows public power to be exercised more effectively. Member states have delegated power to supranational institutions to reap the efficiency gains of an integrated and competitive market, respond to the pressures of global interdependence, protect the environment, consumers, and labor standards. The EU's legal order backs up the extraordinary authority of constitutional law with a technocratic pattern of justification according to which policy questions are understood as problems to be solved rather than compromises to be struck. This pattern surfaces in deliberate attempts to obscure the political stakes of EU decisions by dressing them up as bureaucratic governance. Emblematically, the EU's legislative output is designated with the technocraticsounding terminology of regulations, directives, and decisions rather than as laws or statutes in order to avoid the impression that the EU issues legislation and governs citizens in the manner of an ordinary, coercive political community. ${ }^{98}$

In the parlance of EU scholars, the EU's technocratic pattern of legitimacy is known, following Fritz Scharpf's coinage, as "output legitimacy." Accordingly, "political choices are legitimate if and because they effectively promote the common welfare of the constituency in question." ${ }^{99}$ By contrast, under an input-oriented conception of legitimacy, "[p]olitical choices are legitimate if and because they reflect the 'will of the people'- that is, if they can be derived from the authentic preferences of the members of a community." 100 Modern constitutional systems that institutionalize democratic control and oversight of legislative and executive powers tend to rely on input legitimacy, that is, the idea public power is legitimate because it is subject to the will of those who are governed by it. What transforms the brute power of the state into normatively validated exercises of authority are the guarantees of individual and collective autonomy, equal participation, and due consideration built into democratic procedures. ${ }^{101}$

According to Scharpf, input- and output-oriented modes of legitimation constitute "two dimensions of democratic self-determination."102 Scharpf invokes Lincoln's understanding of democracy as a claim to govern "for the people" to denote output legitimacy, while government "of and by the people" stands in for the input dimension. ${ }^{103}$ Scharpf argues that "plausible legitimacy arguments cannot be

\footnotetext{
${ }^{98}$ When member states formally abandoned the effort to adopt the Constitutional Treaty, and commissioned an intergovernmental conference (IGC) to cobble together its operational provisions into an ordinary amending treaty, one of the first items on the IGC's to-do list was that "the denominations 'law' and 'framework law'... be abandoned, the existing denominations 'regulations,' 'directives' and 'decisions'... retained." Brussels European Council of 21-22 June 2007, Presidency Conclusions. 11177/1/07 REV 1, Annex I, I.1, p.16

${ }^{99}$ Scharpf, Governing in Europe: Effective or Democratic? 6

100 ibid, 6

101 Jürgen Habermas, Between Facts and Norms (Cambridge, MA: MIT Press, 1996); Jürgen Habermas, "On the Internal Relation between the Rule of Law and Democracy."

${ }^{102}$ Scharpf, Governing in Europe: Effective or Democratic? 2

103 Scharpf, Governing in Europe, 358; Fritz W. Scharpf, "Democratic legitimacy under conditions of regulatory competition: Why Europe differs from the United States," in Kalypso Nicolaïdis and Robert
} 
based on purely input-oriented (or 'populist'-Riker 1982) notions of democracy," but must include considerations of how well state institutions serve the public interest. ${ }^{104}$ Like Scharpf, Giandomenico Majone opposes "populist" or "majoritarian" understandings of democracy to a "Madisonian" conception that aims to "share, disperse, delegate and limit power" in order to protect the public interest from majoritarian excess. ${ }^{105}$ Under this conception, non-majoritarian institutions such as judicial review, independent central banks, and expert administrative agencies are no less democratic than elected legislatures.

While Scharpf is correct to observe that participatory institutions do not necessarily guarantee the legitimacy of a regime if they consistently fail to deliver policies that benefit citizens, this does not imply that output-oriented criterion is properly considered a form of democratic legitimation. As I argued in the previous chapter, not all forms of political legitimation are democratic: political regimes have appealed to sources as diverse as divine right and ordainment, antiquity, custom, individual liberty, and class interests to justify their rule. Furthermore, output legitimacy is a criterion that not only democracies but all other types of government must meet in order to ensure their stability and longevity. While it is attractive to think of effective government as a dimension of democratic rule rather than as a criterion external to it, doing so has the effect of defining democracy in a way that is actively hostile to the idea of participatory government. Institutions designed to keep electoral or majoritarian influence at bay can be understood primarily as instantiating a form of democratic legitimacy only at the cost of "refusing the very definition" of democracy. ${ }^{106}$ This is not to argue that administrative institutions are as such incompatible with democracy or to question that epistemic considerations are irrelevant to it; it is rather to observe that output is not a democratic criterion per se. This observation is borne out by the fact that institutions designed to ensure effective government do not necessarily improve the quality of democracy; in fact, their empowerment often comes at the expense of participatory decision-making. Conversely, participatory and representative institutions do not always govern in the public interest or make effective policy decisions. The claim that democracy on balance offers the best procedural device for generating good policy outcomes conflates two expectations that are distinct and, often, discrepant.

Rather than being shoehorned into the category of democratic legitimacy, considerations about whether a set of institutions is better or worse at delivering public goods should be understood as standards of legitimacy in their own right, standards I consider under the term functionalist legitimation. Democracy is a contested and supple concept to be sure, but associating it with muscular epistocratic criteria has what Nadia Urbinati calls a "disfiguring" effect on this important normative concept. ${ }^{107}$

Howse (eds), The Federal Vision (Oxford: Oxford University Press, 2001), at 358; McCormick, Weber, Habermas, and Transformations of the European State, at 270

${ }^{104}$ Scharpf, Governing in Europe: Effective or Democratic? 7

105 Majone, "From the Positive to the Regulatory State," pp.159-160

${ }^{106}$ Sartori, "Constitutionalism: A Preliminary Discussion"

${ }^{107}$ Nadia Urbinati, Democracy Disfigured (Cambridge, MA: Harvard University Press, 2014) 
While Scharpf maintains that the input- and output-oriented dimensions of legitimacy are "generally complementary," the EU's long-running crisis of legitimation suggests that it is engaged in a precarious trade-off between the two. Supranational institutions rely on their greater problem-solving capacity to make up for removing decision-making power from elected institutions at the national level. Put differently, the EU strives to deliver policy outcomes that all citizens can reasonably be assumed to prefer, all else being equal, even if it does not offer citizens many meaningful opportunities for choosing between policy platforms. Acknowledging the fundamentally non-democratic (though not necessarily antidemocratic) nature of the claim to effective government or "legitimation by results" is the necessary step for grasping the EU's distinctiveness as a form of political ordering and critically evaluating its flaws.

In chapter 4, I will evaluate in greater detail why the EU's mechanisms of democratic accountability and representation do not significantly alter its functionalist basis of legitimacy. Taken together, I will argue, the avenues of democratic participation, control, and oversight available for citizens wishing to register their preferences in supranational decision-making processes still take second place to the EU's reliance on output legitimacy. For now, notice that there is a systemic reason why the EU can at best only partially realize the lofty commitments to democratic self-rule enshrined in the Treaty on European Union as amended in 2009.108 As a commitment device for sovereign states, the guiding objective of the European Union is to insulate substantive policy decisions from democratic control. The extent to which functional constitutionalism is designed to disable democratic self-rule far exceeds any "counter-majoritarian difficulty"109 associated with constitutional constraints at the domestic level. Like domestic constitutional constraint, supranational law is meant to hold majorities at bay; unlike a conventional constitution, however, it does not claim to do so in the name of facilitating the democratic process itself. The EU's authority is configured to secure "superordinate goods" such as economic productivity, employment, health and safety, consumer gains, or environmental protection, casting democratic participation as a "subordinate good" that should be met only insofar as it does not interfere with the provision of superordinate goods. ${ }^{110}$

Nowhere is the primacy of the functionalist logic more visible than in the treaty provisions that define the scope of the EU's scope of competence. Although

\footnotetext{
${ }^{108}$ The 2009 Lisbon Treaty has amended the Treaty on European Union to include new "provisions on democratic principles," which affirm "the right [of every citizen] to participate in the democratic life of the Union," emphasize that "citizens are directly represented at Union level in the European Parliament," and recognize the role of political parties as "expressing the will of citizens of the Union." Title II confers duties on the part of Union institutions to "give citizens and representative associations the opportunity to make known and publicly exchange their views in all areas of Union action" and to maintain "dialogue with representative associations and civil society." Art.s 10-11 TEU ${ }^{109}$ Bickel coined this felicitous phrase to refer specifically to the democratic legitimacy of judicial review. I use it more broadly to characterize the apparent constraints constitutional norms place on popular will. Alexander Bickel, The Least Dangerous Branch? The Supreme Court at the Bar of Politics (New Haven: Yale University Press, 1986)

${ }^{110}$ The distinction between subordinate and superordinate goods draws on Ian Shapiro, Democratic Justice (New Haven, CT: Yale University Press, 1999), 23.
} 
the EU's authority is limited to the powers member states have explicitly conferred to it, its outer bounds are contested, as in any regular federal system. The treaties enshrine the principles of subsidiarity and proportionality as guides for resolving questions of competence. According to the principle of subsidiarity, in areas which do not fall within its exclusive competence, the Union shall act only if and in so far as the objectives of the proposed action cannot be sufficiently achieved by the Member States, either at central level or at regional and local level, but can rather, by reason of the scale or effects of the proposed action, be better achieved at Union level. ${ }^{111}$

Phrased more simply, on matters where the treaties do not establish a European competence to act, the Union is allowed to claim authority only if member states cannot effectively carry out the same objective acting alone. The subsidiarity principle does not say, for instance, that the European Union should act only where its actions would be more democratically legitimate, or more conducive to individual autonomy, in comparison to member states acting singly. Rather, the criterion guiding any proposed extension of EU competence is its conduciveness to the effective exercise of power rather than some alternative principle such as popular participation, cultural specificity, distributive justice, or affected interests.

The functionalist phrasing of the subsidiarity principle also undermines the view that supranational governance is about carrying the democratic principle of affected interests beyond the state. It has been argued that supranational institutions provide a forum that compels states to take into account the effects their decisions have on non-citizens, and as such, expands the scope of democratic participation. ${ }^{112}$ This is not, however, the rationale behind the subsidiarity principle, which presumes that decisions taken at the national or sub-national levels are by default more democratically legitimate, but that reasons of effective government may outweigh the presumption of proximity to the citizens. In other words, far from awarding competences to the EU based on the democratic valueadded of supranational decision-making, the treaties tacitly admit a trade-off between legitimation based on efficiency and democracy.

Similarly, the principle of proportionality, which immediately follows the subsidiarity clause, provides that "the content and form of Union action shall not exceed what is necessary to achieve the objectives of the Treaties." 113 Here, too, the criterion by which the EU's authority is established and circumscribed is one of effective government rather than any other available standard such as democratic legitimacy, in which case the same clause might read: "the content and form of Union action shall not exceed what the demos / demoi authorize(s) it to do." Or, a rights-based version of the same principle would commission the EU with authority required to do "what is necessary to ensure the protection of fundamental rights."

\footnotetext{
${ }^{111}$ Art 5(3) TEU, emphasis added

${ }^{112}$ For instance, Maduro argues that European integration helps to "[correct] the constitutional limits of national political communities." Miguel Poiares Maduro, "Sovereignty in Europe: The European Court of Justice and the Creation of a European Political Community," in Mary L. Volcansek and John F. Stack, Jr. (eds), Courts Crossing Borders: Blurring the Lines of Sovereignty (Durham, NC: Carolina Academic Press, 2005).

${ }^{113}$ Art 5(4) TEU, emphasis added
} 
As these hypothetical alternative formulations illustrate, the EU's authority is founded on a claim to effective government, which simultaneously commissions and delimits it. Taken together, the principles of subsidiarity and proportionality imply that the Union can arrogate as much power as the treaty objectives warrant, and that any attenuation of democratic control that results from such arrogation of power is compensated by the gains in effective decision-making. By the same token, however, EU institutions lack the authority to revise, question, or curtail the objectives enshrined in the treaties, however intense democratically expressed popular preferences may be in favor of doing just that.

None of this is to say that the logic of effectiveness that guides the scope and nature of supranational power is unique to the European Union. Power-building, as Alfred Stepan points out, is an essential objective of "coming-together federations," "whereby previously sovereign polities agree to give up part of their sovereignty in order to pool their resources to increase their collective security and to achieve other goals, including economic ones." ${ }^{114}$ As I argued in the previous chapter, far from being unique to the EU, this logic was prominent in the constitutional founding of the US. As the Federalist Papers repeatedly noted, the US Constitution was intended, among other things, to endow a federal government with the power to provide for internal and external security, promote commerce, and oversee territorial expansion than the several states acting alone or in a looser form of alliance. And as Spinelli presciently observed in 1956, "when it comes to the supranational unification of certain aspects of political life," as Europeans were at the time attempting to do, "one cannot fail to take into account the American model, because the logic of the American system is the very logic of political power building." 115 What makes the European Union distinctive, however, is the particular weight it assigns to the logic of power-building compared to the alternative logics of democratic and rights-based legitimacy. Its institutional structure, scope of action, and legal order rely overwhelmingly on the claim to effective governance, at times even acknowledging (as the subsidiarity and proportionality principles implicitly do) that such gains come at the cost of democratic control.

\section{(iii) Epistocracy and its discontents}

To argue as I have done here that the authority of the EU's supranational legal order is premised on a claim to functional effectiveness is not to say that the EU actually fulfills that promise, just as absolutist monarchies could appeal to divine sanction to justify their authority in the absence of any celestial annunciation to that effect. What I advance is a contestable claim about the justificatory narrative that

\footnotetext{
${ }^{114}$ Alfred Stepan, "Federalism and Democracy: Beyond the US Model," Journal of Democracy, vol.10 (1999), no.4, pp. 19-34, 21

${ }^{115}$ Altiero Spinelli, "The American Constitutional Model and Attempts at European Unification," The Federalist, vol.47 (2005), no.2, pp.115-125. Available at: http://www.thefederalist.eu/site/files/PDF/EN/2000/2005-2-EN.pdf
} 
shapes the European Union's legal order and the dominant register in which its discursive appeal for the allegiance of member states and citizens takes place. Put differently, I treat the commitment to effective government as an "aspiration and not fact." 116 To be sure, if the EU consistently fails to fulfill its promise to deliver better policy results than member states acting alone, then it will need to look elsewhere for a meaningful discourse of legitimation. Indeed, the EU's inability to swiftly resolve the euro crisis has done much damage to the credibility of its claim that it can govern monetary policy more adroitly than member states. In sum, describing the EU's legal order as a system of functional constitutionalism does not imply that supranational institutions are, as a matter of fact, more effective than member states in achieving the policy outcomes that have been delegated to them. Rather, it highlights the fact that the authority of Europe's supranational constitutional order relies on a functionalist logic of legitimation to a far greater extent than domestic constitutional regimes. This reliance brings with it a distinctive set of challenges and contradictions.

The European Union's functionalist basis of legitimation is highly vulnerable to a number of objections. How far (if at all) can gains in policy effectiveness make up for losses in democratic control? If citizens cannot regard the decisions that govern them as having been authorized by them or by the elected representatives who serve at their pleasure, does it matter that these are, by some objective measure, the best decisions available in the circumstances? Is such an objective measure of the public interest available outside of what the people and their representatives decide for themselves? This is where the European Union parts ways with democratic systems of government. To the extent that it privileges a purportedly value-neutral ideal of policy-making as problem-solving, the EU represents an epistocratic impulse that distrusts democratic majorities as shortsighted, selfish, and likely to renege on their commitments. Defined by David Estlund as the "rule of the knowers,"117 epistocracy asks citizens to "surrender" their own judgment on political questions to experts who are better placed than them to address political questions. ${ }^{118}$ Although the decision-making structures of the European Union typically depend on elected representatives in the Council and Parliament to negotiate desired outcomes in broad outline, it leaves their detailed implementation to technocrats within the Commission and within domestic administrative institutions. However, the extent and significance of the power wielded by the supranational technocracy throws into serious doubt the adequacy of functional effectiveness as a standalone source of legitimation, particularly when it comes at the expense of democratic self-rule. As the EU's roster of competences has grown, along with the salience of the issues entrusted to it, the functionalist claim has become increasingly inadequate in legitimating its authority.

\footnotetext{
${ }^{116}$ Hendrickson, Peace Pact, 21

117 David Estlund, "Beyond fairness and deliberation: the epistemic dimension of democratic authority," in J. Bohman and W. Regh, Deliberative Democracy. Essays on Reason and Politics (Cambridge, MA: MIT Press, 1997), at 181-183.

118 Ibid.
} 
Lastly, although democratic constitutionalism permits similar attenuations of decision-making from democratic control, it nevertheless allows for a large measure of flexibility both at the level of ordinary legislation and constitutional change. By contrast, functional constitutionalism is far more rigid. The inflexibility and fixed teleology of supranational law makes it difficult for member states to change course in the face of sustained popular discontent, and renders design flaws exceedingly difficult to correct in the face of downstream systemic imperatives. Entrenched against revision, the European edifice risks becoming ineffective as well as undemocratic, undermining any plausible claim to outcome-based legitimacy in the name of which democratic attenuation was justified in the first place. In other words, the EU's stark prioritization of effective over democratic government is selfdefeating: it threatens the effectiveness of the supranational institutions as well as their democratic legitimacy.

\section{(iv) Conclusion}

In this chapter, I outlined the distinctive features of what I call the European Union's system of functional constitutionalism. In particular, I highlighted three features of the EU's legal system, namely, the functionally specialized scope of authority, its teleological rigidity, and its functionalist pattern of legitimation, which premises the EU's authority on its purported ability to make government more effective (rather than more democratic or more conducive to individual liberty). Each of these features differs to some degree from instantiations of the constitutional idea within the context of the sovereign state, which is traditionally understood to entail a comprehensive, fully autonomous, and democratically authorized form of political ordering. Nonetheless, I argued that the European Union fulfills a recognizably constitutional purpose: it responds to the formidable challenge of enforcing limits on public power, and employs recognizable constitutional mechanisms in doing so.

In the following chapters, I will delve into substantive areas of EU law to deepen this contrast between functional constitutionalism and other models of constitutional rule. My aim will be critical: most of these alternative models are far more attractive normatively than functional constitutionalism, but alas, they do not capture the EU's current configuration. Even as aspirational accounts, they underestimate the pervasiveness of the teleology of market-building within the EU's legal and institutional structure, and the extent to which that teleology thwarts attempts at democratizing the European Union and broadening its normative horizons beyond the provision of material affluence.

In the next chapter, I will address the question of whether the European Union can be considered either as a human rights organization or as the supranational instantiation of a conventional rights-based model of constitutionalism. In response, I will argue that the EU's regime of fundamental freedoms differs from each of these models on account of its narrow focus on economic mobility. In Chapter 4, I will consider the question of whether the European Union can be considered a system of democratic constitutionalism, and 
argue that despite the expansion of mechanisms of participatory decision-making, the most important participatory mechanism within the Union remains that of market-centered activity by private persons. In Chapters 5 and 6, I will consider the question of whether the European Union is a cosmopolitan federation devoted to promoting the "inclusion of the other." 119 Here, too, the EU's functional constitutionalism frustrates lofty expectations. The twin principles of free movement and anti-discrimination, while seemingly universalistic on their face, are in fact quite limited in their material and personal scope, protecting member state citizens who engage in cross-border commercial activity while offering little to third country nationals or non-mobile EU citizens. The point of these substantive sketches of EU law is not simply critical, but also conceptual: I hope to throw the distinctive configuration of functional constitutionalism into high relief by contrasting it with more familiar paradigms, such as those of democratic, liberal, and cosmopolitan constitutionalism. While we may yet hope that the EU will come to approximate these aspirational paradigms, for the moment they remain that: aspirational.

\footnotetext{
${ }^{119}$ Jurgen Habermas has coined this phrase to describe the project of uncoupling democratic participation from the nation-state. See especially, Jurgen Habermas, "The European Nation-State: On the Past and Future of Sovereignty and Citizenship" in The Inclusion of the Other (MIT Press: 1998),
} 